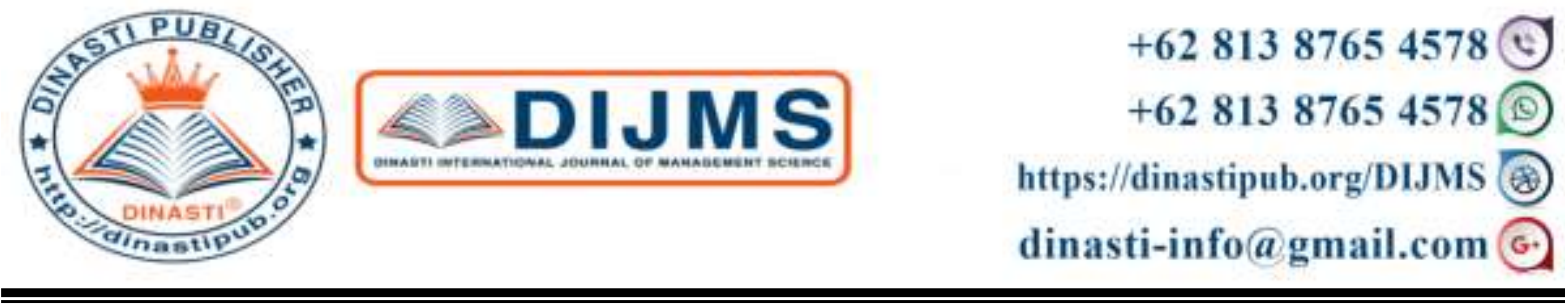

\title{
CONCEPTUAL GREEN DEVELOPMENT IN ORGANIC PRODUCT: A CONSUMER BEHAVIOR APPROACH
}

Diana Lutfiana ${ }^{1)}$, Nur Endah Retno Wuryandari ${ }^{2)}$

1) 2) Universitas Mercu Buana, Jakarta, Indonesia

\begin{tabular}{|c|c|}
\hline $\begin{array}{l}\text { ARTICLE INFORMATION } \\
\text { Received: } 19^{\text {th }} \text { April } 2020 \\
\text { Revised: } 25^{\text {th }} \text { April } 2020 \\
\text { Issued: } 14^{\text {th }} \text { May } 2020 \\
\text { Corresponding author: } \\
\text { Diana } \\
\text { E-mail: } \\
\text { diana.lutfiana@mercubuana.ac.id } \\
\text { nurendah.retno@mercubuana.ac.id }\end{array}$ & $\begin{array}{l}\text { Abstract: The Indonesian Organic Agriculture } \\
\text { Statistics (SPOI) recorded the number of consumer } \\
\text { demand for organic products increased } 54 \text { percent } \\
\text { compared to the previous year. For more detailed, } \\
\text { other data shows } 18 \text { percent of customers in Southeast } \\
\text { Asia are willing to pay more to buy organic products. } \\
\text { The purpose of this study is to predict consumer } \\
\text { behavior and investigate in purchase intention organic } \\
\text { product which became a trend as well as an attractive } \\
\text { business opportunity in the future. This research using } \\
\text { the shopping at hypermarkets which is located in } \\
\text { jakarta. The research objects have attitude, perceived } \\
\text { value, and attribute as factors affecting them to buy } \\
\text { organic. The result each factor is positive and } \\
\text { significant influence towards Intention to Purchase the } \\
\text { green product. The Coefficients table in this research } \\
\text { showed the value of attribute as the highest score of } \\
\text { consumer behavior in purchase the green product } \\
\text { Green action can implement a new trend of lifestyle in } \\
\text { consumption organic food in Indonesia. Those all need } \\
\text { involvement in marketing activities and will become } \\
\text { conceptual strategic for green products that examined } \\
\text { in this research. }\end{array}$ \\
\hline
\end{tabular}

\section{INTRODUCTION}

Regarding to the effort to save the earth, one of the essential things is attempting the green development. Moreover, the awareness to keep the environment safe gets decreased in over ten years, this is the thing that is found by research that met the fact that green product / organic product purchasing behavior obtains greater. Liobikiene and Bernatoniene (2017) has stated that the awareness towards environmental health in constant that leads into the organic product consumption, there are many things that are questioned. One of them is that why the 
interest towards saving our environment sometimes does not give impact in purchasing environmentally friendly products entirely? Does this awareness is also supposed to influences your habit to purchase and change daily consume with environmentally friendly products in altogether? Because the excessive use of the conventional products can lead into the situation that is dangerous for life sustainability in earth and the purchase and use of environmentally safe product or organic product is the solution that can prevent that threat. On the other hand, the research and marketing sides are advisable to maintain and develop the awareness and interest of people towards organic product consume are to be highlighted [1].

In Indonesia, organic market growth is around $15-20 \%$ and continues to increase due to it is driven by an increase in people's purchasing power and reasons for a healthier life [2]. All over the world organic growth is increasing every year, Millissa F.Y. Cheunga, W.M. Tob (2019), the organizations have been paying more attention to market green products. In the European Union (EU), 26\% of consumers purchased green products frequently while $54 \%$ of EU consumers purchased them sometimes (The European Commission, 2016) [3]. In China, demand for organic and green food has surged because of increasing disposable income (McCarthy et al., 2015). Young consumers have high intention to purchase green products (Chekima et al., 2016; Yadav and Pathak, 2017) and health consciousness and environmental consciousness influenced their purchase of organic food (Rana and Paul, 2017) [4].

\section{Background of Study}

Indonesia's government and local organizations have been dedicated to organic agriculture training, research, and promotion. Organic agriculture in Indonesia has achieved a degree of legitimacy and authority [5]. The consumers can find a variety of fruits and vegetables that are targeted sales transactions of up to Rp 350 million [6]. The increase in Indonesia's population relates with the increase in vegetable consumption in Indonesia has been started towards Consumption and Organic as Lifestyle Trends in Indonesia, as DR. David Wahyudi, the Professor of Food Science and Technology, from University of Bakrie, and Indonesia and Managing Editor of the Asia Pacific Journal of Sustainable Agriculture, Food \& Energy, stated that the history of the organic movement in the world happened a long time ago [7].

Over the previous decade, organic food farming in developing countries has massively advanced in response to worldwide transformations in consumption inclination and cross-border purchasing requirements [8]. Multiple competitive studies found in the literature clarify organic food consumption behaviour [9]. The majority of these studies focused on developed economies perhaps due to increased demand in the developed world. Information presented via the literature on the effort about how to grow their own vegetables at home with the concept of urban farming such as micro green and aquaponic [10].

The efforts attempted to find research in the purpose of measuring the awareness of people in keeping the environment safe related to the selection of organic products are conducted several times by many parties. One of the methods is comparing organic farming to the conventional agriculture. In the field, it can be inferred that the intention of consumers 
to purchase organic products is not concretely known. In Jakarta, this case became a study to obtain the result observation towards consumer's behavioral intention in purchasing organic food to be investigated. Green marketing orientations was used for the investigation, as it is one of the most widely used theories for investigating the relationship between attitude, perceived value and attributes [11], environmental concerns, and care for green products [12].

In Indonesia, a survey conducted by Nielsen's New Global Health and IngredientSentiment Survey online and published [13]. This survey looks at various consumption behaviors which are then claimed by respondents that Indonesians are starting to care more about the food they consume. In fact, most of respondents claimed to follow certain dietary patterns and the other reasons consumers choose organic products that they want to live healthier due to the advantages of organic products compared to non-organic products, which are free of pesticides and free of GMOs. it is about environmental and animal welfare issues. The information transmitted about the advantages of consuming organic product in environmental campaigns is to show the value of benefits and effects for health and environment [7].

Recently, organic food consumption has become lifestyle as it shifts to be trend. Nowadays, people tend to be more aware for the health by consuming organic product contains no addictive substance, preservatives, additional flavor or coloring which happens as it is getting more urgent because health is the thing that is not supposed to be compromised for longer life. Organic food is served and sold without pesticide or fertilizer made from artificial or synthetic ingredients in fabrication in the process if growing, as they are used in conventional product that normally uses sewage sludge, bioengineering or ionizing radiation, thus this thing support health food in real way [13]. However, Indonesian organic food consumers are mostly from high class people and have enough comprehension about organic product. Therefore, hypermarket is supportive place in promoting organic product and the basic to develop the business in retail. Then, the duty of the companies or organic products provide can involve themselves towards the consumers' purchase intention. The attribute of the products must be better than in the conventional products, e.g. the package served and content of the product (information) [14].

Therefore from this perspective, it is entirely states that cost-benefit or price does not become an essential thing towards organic food. Singh and Verma (2017) has revealed from their study that the perceived price or the cost-benefit has given significant factor for the organic product consumers in Jakarta to purchase. The attribute of the organic product can be the last influential factor towards the purchase intention after the environment saving campaign and promotion [15]. Nowadays retail companies develop the quality and package of organic food to become more ideal to be consumed. If the package of the organic food shows good quality, the consumers will consider to choose it. The function of the attribute is as the information about the product and as promotion tool for the consumersThus, the package of product must be filled with proper information, language has important role. Package is used as media and presented as precious news. The existence of language is not only a tool to describe a reality, but can determine the image (image) that will appear in the minds of the public [16]. 
Moreover, in any pertinent things of perceived value to understand the consumer's behavior for purchasing organic food as factors, literature states that various attributes have proven to find out. Conducting several studies related to the health benefit as the most important thing as attribute that influences consumers selection.of the organic food shows good quality, the consumers will consider to choose it. The function of the attribute is as the information about the product and as promotion tool for the consumers. Sirgy (1991) stated that the researcher has found that giving informing properly and indirect marketing of product to consumer plays pivotal role to make the product more trustworthy and become one point plus as attribute. Above all, the most important that is desired to be memorized by the consumer which then influences the purchase intention is label. Carlson et al. (Bing and Chaipoorpirutana, 2011) has declared that labeling is influential for customer's purchase intention and the label is supposed to contain brand, composition, expiry date and nutrition. It must be significant as label is medium for information and promotion of the product [17].

The companies must execute green marketing strategy to enhance the value of their product because the organic food is now getting more popular in society. One of them is Danny, the owner of "Amazing Farm", he says that there is a process of the organic food demand which now is increasing. As supplier, he must be consistence in giving the set quality and the delivery process, if the products fulfill the requirements, costumers usually see the brand and automatically they will increase the frequency or the amount of the purchase or delivery. Those mean green marketing is needed in the process of marketing activity [6]. Jain and Kaur (2004) has asserted that green marketing equals a process that consists of all marketing strategies that are carried out and developed constantly in order to maintain the awareness of people in saving environment in their daily life as behavior [18].

In Jakarta, there are retail companies which are now selling organic products are Carrefour, Food Hall and Kemchick. The researcher sees those places as reliable market which give influence for the consumers towards purchase intention. The place that is convenient, hygiene and of course with proper service will make consumer will not worry of the quality. Ramadania (2003) has denoted that trust has many dimensions, for example the reputation, security and convenience of the market place where the product is sold, along with the advantage. The three factors of the marketing place are the most selected place to visit by the customers because the place represents the quality of the products sold inside and guarantees the storage system. Another way to educate the customer to be participant in giving care to the environment beside serving reducible shopping bag is placing the organic product neatly in clean place or storage, so that the consumer has no doubt towards the quality of the product.

\section{Identification of Issues}

Recently, the better opportunity to sell vegetables is on supermarkets, hypermarkets and special outlets that are modern market where various fresh vegetables are sold and the consumers target are those who come from middle and upper class. The fact that the prices of the vegetables there are expensive comparing to the vegetables sold in traditional markets does not make them think twice to purchase vegetables in modern markets as it has become 
lifestyle and also related to the hygiene, freshness and convenience. But some of consumers choose modern market instead as they earn more income and better understanding or acknowledgement, exchange and other motives [7].

Retail companies which are now selling organic products in Jakarta are Carrefour, Food Hall and Kemchick. The researcher sees those places as reliable market which give influence for the consumers towards purchase intention. The place that is convenient, hygiene and of course with proper service will make consumer will not worry of the quality. Modern market is supportive place in promoting organic product and the basic to develop the business in retail. Then, the duty of the companies or organic products provide can involve themselves towards the consumers' purchase intention Organic product purchase can indicate a regular and sustainability in income earning [18].

China has experienced a great transformation and financial prosperity in over the last three decades which this situation can upgrade the lifestyle of the people as the influence of expanding the organic product marketing as their earning get increased gradually. However, although China's food safety becomes an issue circulated beyond the country, organic food product is slightly finite [11]. The main aim of attempting study is to find out and analyze the factors that predispose consumer's organic food purchase intention in Jakarta. As the summary, there are several positive influences of the purchase intention that give impact to consumers in Indonesia to gain more awareness towards organic food as the main menu due to health issue.

\section{LITERATURE REVIEW}

Attitude: Awareness is needed in consumers' purchase intention towards green product. Chen (2009) believes that environmental attitude determines someone's attitude towards green product, and if someone intends to be healthier, he will show positive habit towards green product. Attitude can be learnt in having sight how someone responds or reacts in showing his behavior [12]. Chen and Chai (2010) assimilate from Blackwell et.al (2006) and Schultz and Zelezny (2000) define that attitude as an action which shows what consumers like and dislike, also the attitude they show towards the environment is begun from the concept of individual and based on each person's perception to be a part of the whole environment [16]. To grow the trust towards green product, retail companies must make the consumers trust to their products [18].

So, if the attitude seems more positive, they will keep their intention in showing it or the reverse. In marketing business, there must be an influence of businessman to give positive things inside the product to the consumer, so that the positive attitude can be increased by the consumers as the feedback. Syed Saad Hussain (2012) states that the structure of green product's advantage supports the environment and individual as the main parameter that endorse the consumers' purchase intention indirectly. The natural feeling and real regarding to the advantage of the product will give effect to the consumers' purchase intention [17].

Perceived Value: : Swait and Sweeney (2000) have proven that the influence of customer's perceived value reflects on the purchase intention towards organic product in retail industry where the perceived value influence their purchase in behavior in many 
classifications [15]. They are price value, functional value, emotional value and social value. Meanwhile, Chen and Quester (2006) Cornin et al., (2000) and Pura (2005) has revealed that perceived value plays pivotal task in marketing side as perceived value can be considered as indicator of competition side and also the differentiator from one to another [17].

As to explain the result finding of Swait and Sweeney, the mentioned aspects show that each consumer has different perceived value, moreover the other additional factor that give influence the perceived value, they are emotional and needs meanwhile the basic and principal things are price and quality. Perceived value of each consumer which means emotional and social sides are supposed to be the concern of companies to be developed and may be researched or surveyed along with keep bettering the price and quality of organic product in order the business can remain stable or tend to increase. Sweeney J.C. \& Soutar, G.N (2001) has found that information of product transferred to customer is important regarding to the emotional side of customers in other words, it becomes influential thing in purchase intention. Customer will gain more information and keep comparing to other products and they are recently have better understanding of trustworthy value of products and service and it will create certain image or branding for the product and build more loyalty and profit [13].

Attribute Product: There are several attributes mentioned in pertinent literature related to the organic food to meet the comprehension of consumer behavior. Quoted from Loebnitz and Aschemann-Witzel (2016) stated that the main attribute, in other word is the most logic and concrete, organic food consumption is realized as important to health [2]. The next one is the taste and awareness towards environment that are also become the consideration of consumers of organic products (Thogersen, et al, 2015). A study in Bangkok conducted by Roitner Schibesberger, Darnhofer, Somsook and Vogi (2008) has found that organic product recently has become a lifestyle along with delicious taste. And the most recent study was performed in Germany, on survey from 9.470 households also the result of data analyzing from panel (Janssen,2018) has declared that the organic food purchase is the main indicator of the behavior of people towards their care for health maintaining and earth protecting [4].

However, based on the argument of the study found by Dolezalova, Picha, Navratil, Vesela and Svec (2016) it was revealed that consumers do not give focus on the food display also the taste as their main concern is on health. For better comprehension on literature, above is Table I as the classification of organic food characteristics, the test of dependent variables, the uninfluenced studies and the type of relationship as the result found. To be more specific, the table shows the quantitative studies that were observed in the needs of variables of interest [3].

Intention to Purchase: Shciffman and Kanuk (2011:487) found that the final decision to purchase can be made after considering two or three other products as choices. Someone will make one decision to purchase on product after selecting two or three same products from different brands that are easily found in market. However, Ma and Yang (2016) stated that good quality is the main reason for customers as consideration to purchase a product that can satisfy the most. On the other hand, excellent service can be built in 
employee by maintaining the attitude or behavior helped with keep innovating and proper empowerment. Moreover, well organized system among employees becomes pivotal factor towards purchase intention [4].

Purchase intention of organic products also influenced by many elements, they are comprehension towards health, environmental awareness, product availability, perceived quality, product distribution, nutritional value comparing to other products. Rana and Paul (2012) highlighted that health reason is the only thing in customer's mind to consider the purchase of organic supported by the availability and quality of the products in the market [7]. It is also known that the relationship between purchase intention and many variables like price, value, people's awareness towards organic/green product's effect to environment (Iyer, Davari and Paswan, 2016) this is the same result that has found by Yadav and Pathak (2016). Maichum, Parichatnon and Peng (2017) revealed that there are other things that are perceived by the people, they are environmental awareness, knowledge and attitude towards which give great impact in intention to purchase green product [3].

Green Marketing: There are plenty of international companies, governmental institutions, academicians and some other related institutions nowadays highlight and concern towards environmental awareness which has been an issue that gives threat for earth in decades. Moreover, the consumers are wise and intelligent enough to select the best product to be consumed in daily life. This fact supports the related several markets to develop and produce reusable and reducible products to attract consumers. Green product consumes promotes health towards human and environment, this is the fact also solution of all worries towards environmental issue, supported with some market that is actively prioritize green products due to the consumer's demand (Wang, 2017) [2]. Laroche et al,. (2001) has given additional information that the consumer's shopping habit reflect the positive attitude that becomes the real action regarding to green environment or health issue. As people now give more concern to cfc and reducible products, the fact found that consumers have no doubt to pay more money to purchase products that are reusable and reducible [3].

There are three levels that can indicate the fluctuation of the change. To be more specific, promotion and advertisement are two important things that must be maintained and executed well for effective marketing. "Green action" or green product marketing strategy in fact can inspire other area to do which means promotes pride and for the first region or area as initiator. Those aspects must be combined well in marketing activity for better and greater marketing strategy of manufacturing [4].

\section{RESEARCH METHODS}

The study is conducted on primary and secondary data collection, where the secondary data is obtained from research from papers like articles, information from internet and the primary data is derived from direct survey. The survey was carried out involving 200 consumers who are finished shopping. The method uses descriptive analytical study and the analysis is helped by the using of SPSS Software and Microsoft Excel. The find the result is proven by hypothesis and the chi-square test. Meanwhile, the data interpretation, tables are designed to get better understanding and more structural classifications for the survey. 


\section{RESULTS AND DISCUSSION}

Profile of the Respondents: The researcher describes the data of respondent which includes 200 people. The characteristic of respondent that is described include: age, job, and education level. In the region of Jakarta the majority of the respondents are females, while, regarding their age between $25-34(62 \%)$ with the values 70 . There are respondents with the profession as employee have significant percentage of (46,50\%). Respondents in the bachelor degree level have the value $88(66,50 \%)$.

\section{Summary of Findings:}

Attitude: Respondents' respond to the attitude in intention toward organic food for all indicators have the highest mean 4, 01 was on statement "saya bersedia membeli produk berkualitas tinggi saat keadaan ekonomi sedang baik."

Perceived value: Respondents' respond to the attitude in intention toward organic food for all indicators have the highest mean 4, 41 was on statement "saya merasa bertanggung jawab terhadap kesehatan saya."

Attribute: Respondents' respond to the attitude in intention toward organic food for all indicators have the highest mean 3,61 was on statement "saya suka membeli produk yang kemasannya menarik."

\section{CONCLUSION AND SUGESTION}

\section{Conclusion}

1. The conclusions are based on the Coefficients value that there is attitude of customers, perceived value and attribute of products has significant value towards Intention to Purchase the green product in supermarkets in Jakarta.

2. To increase the customers' intention to purchase green products which is increasing the attitude of customers due to the highest result shows that attitude is the main factor that has intention to purchase organic foodwhile the condition of economy is good.

\section{Recommendations}

1. The businessman or producer (big scale agent) focuses on the markets that are potential by dividing or classifying the market target based on age 25-34 (employees and professional)

2. Segmentation (the most influential) becomes an aspect that give great impact and later will be a consideration for the producer of organic product to be better in quality by times.

3. The development of social media such as Facebook, Instagram, Twitter is no longer a stranger to the ears of Indonesian people, especially in Jakarta [19]. Therefore, to increase business retails' exposure towards organic products with the offline in hypermarkets/big supermarkets as well as a broader to approach the segmentation through social media. 


\section{REFERENCE}

Arminda doPaço, Chris Shiel, Helena Alves, A New Model for Testing Green Consumer Behaviour, (2018), doi: 10.1016/j.jclepro. Journal of Cleaner Production 2018.10.105 Borin \& Krishnan, C.D. [n.d.] Consumer Effect on Environmental Effect in Product Labelling Norm.

Scialabba. [2005]. Organic Agriculture, Poverty Reduction, and the Millennium Development Goals. ADB Institute Discussion Paper No. 54

Kuo-Chien Changa, Chia-Lin Hsub, \& et,al. [2019]. How green marketing, perceived motives and incentives influence behavioral intentions

Jyoti Ranaa, \& Justin Paulb. [2017]. Consumer behavior and purchase intention for organic food: A review and research agenda Budi Setiawan. [2015]. Teknik Praktis Analisis Data Penelitian Sosial \& Bisnis dengan SPSS. Andi Yogyakarta.

From https://www.beritasatu.com/kesehatan/574517/permintaan-produk-organik-meningkat54.

From https://www.beritasatu.com/gaya-hidup/518612/farm-to-table-2018-sajikan-buah-dansayur-organik-terbaik-di-indonesia).

From https://aoi.ngo/web/tren-konsumsi-dan-gaya-hidup-organik-di-indonesia/.

Madhu Singh. \& Vinoo Johnson Massey. [2019]. A Study on Green Products and Customer Satisfaction towards Green Products with Reference to Environmental Protection. ISSN: 0374-8588 Volume 21 Issue 11, November 2019

Euis Dasipah, Haris Budiyono, \& Meilan Julaeni. [n.d.]. Analisis Perilaku Konsumen Dalam Pembelian Produk Sayuran di Pasar Modern Kota Bekasi.

Xuhui Wang, Frida Pacho, Jia Liu, \& Redempta Kajungiro. [2019]. Factors Influencing Organic Food Purchase Intention in Developing Countries and the Moderating Role of Knowledge.

Isabelle Cristina Galindo Curvelo, Eluiza Alberto de Morais Watanabe \& Solange Alfinit. [2019]. Purchase intention of organic food under the influence of attributes, consumer trust and perceived value.

From https://investor.id/lifestyle/tren-konsumsi-dan-gaya-hidup-organik-di-indonesia-makinmeningkat.

Mohd Rizaimy Shaharudin, \& Shamsul Jamil Elias. [2010]. Purchase Intention Organic Food; Perceive Value Overview

Gabriela O. Chiciudean, \& et.al. [2019]. Organic Food Consumers and Purchase Intention: A Case Study in Romania

U Farid Hamid. [n.d.]. Media dan Konstruksi Realitas.

Aiyun Xiao, Shaohua Yang, \& Qaisar Iqbal. [2018]. FactorsAffectingPurchaseIntentionsinGenerationY: An Empirical Evidence from Fast Food Industry in Malaysia

Mahnaz Tabassum, \& Wilson Ozuem. [2019]. New Product Development and Consumer Purchase Intentions: A literature review. 
Chen, \& Chang. [2012]. Enhance Green Purchase Intention The Roles of Green Perceived Value, Green Perceived Risk, and Green Trust,. Management Decision Vol. 50 No. 3, 2012.

Elly Yuliawati, Rangga Kusuma Nagara, \& et.al. [n.d.]. Self-Image Development and Images of Kalibaru Cilincing Area as One of North Jakarta Tour Destination Through Instagram Social Media. 